\title{
A referenciamutatóként használt bankközi kamatlábak integritása*
}

\author{
Béres Dániel
}

Jelen tanulmány bemutatja, hogy miként váltak a bankközi kamatlábak a gazdaság és a pénzügyi világ világítótornyaivá. A tanulmány a Budapesti Bankközi Forint Hitelkamatláb (a továbbiakban: BUBOR) példáján keresztül értékeli azoknak a módszereknek a gyakorlati alkalmazhatóságát, amelyekkel a referenciamutatóként használt bankközi kamatlábak manipulációjára irányuló kísérletek visszaszoríthatók, illetve feltárhatók. Felhívja a figyelmet, hogy egy fizetési rendszeren alapuló referenciakamat-előállítási modell jelentős mértékben hozzá tudna járulni a referenciamutató előállitása kapcsán jelentkező manipulációs kockázat eliminálásához. Két eltérő időszakban, 6-6 szcenárió mentén vizsgálja, hogy az adott referenciamutató (BUBOR) milyen mértékben van kitéve egy esetleges manipulációnak. Megállapítja, hogy az alacsony kamatkörnyezet és a jegyzések alacsony szórása az alkalmazott módszertannal együtt gyakorlatilag a nulla közeli szintre csökkentette a manipulációs potenciált. Ez egyben azt is jelenti, hogy azokban az időszakokban, amikor a jegyzések volatilitása alacsony, a referenciamutató képzésének ellenörzésére fordított erőforrások mennyiségének a csökkentése indokolt és alátámasztott. Az egyes módszerek bevezetése a jegyzésben részt vevő intézmények alkalmazkodását válthatja ki, ami gyengítheti, illetve erősítheti is egy-egy módszer hatékonyságát.

Journal of Economic Literature (JEL) kódok: B25, B26, C10, C52, D53, D69, G28 Kulcsszavak: bankközi kamatláb, referenciamutató, módszertan, BUBOR, LIBOR, manipuláció

\section{Bevezetés}

A bankközi kamatlábakat a hazai szakirodalomban előszeretettel jellemzik úgy, mint a pénzügyi világ világítótornyait (MNB 2000; Erhart - Mátrai 2015; Horváth et al. 2017). A képszerű megfogalmazás annál is inkább helytálló, mivel a gyakorlatban a bankközi kamatlábak számos pénzügyi eszköz árára vannak közvetlenül vagy közvetett módon hatással. Amellett tehát, hogy fontos szerepet tölt be a monetáris politika megvalósításában, a piaci szereplők számára is kiemelt jelentőséggel bír.

\footnotetext{
* A jelen kiadványban megjelenő írások a szerzők nézeteit tartalmazzák, ami nem feltétlenül egyezik a Magyar Nemzeti Bank hivatalos álláspontjával.

Béres Dániel a Budapest Metropolitan Egyetem föiskolai docense.E-mail: dberes@metropolitan.hu

A magyar nyelvű kézirat első változata 2018. december 4-én érkezett szerkesztőségünkbe.
}

DOI: http://doi.org/10.25201/HSZ.18.1.3460 
Speciális jellegéből adódóan ma már úgy tekinthetünk a referenciamutatóként használt bankközi kamatlábakra, mint közjószágokra (Horváth et al. 2017), amelyek előállításához a piaci szereplők aktív közreműködése szükséges. A közlegelők tragédiája - a Hardin-féle (1968) koncepcióhoz hasonlóan - a referenciaként használt bankközi kamatlábak esetén is a túlhasználatból ered. Jelen esetben azonban nem a közjószág veszíti el értékét (kvázi szűnik meg), hanem azon ösztönzők száma növekedik, illetve jellege változik meg, amelyek a közjószág magánérdekké transzformálására irányulnak. Egyszerúbben fogalmazva, minél több pénzügyi eszköz árazása, valamint értéke függ a referenciamutatóként alkalmazott bankközi kamatlábak alakulásától, annál nagyobb az ösztönző erő a kamatláb alakulásának befolyásolására (manipulációjára) is.

A 2008-ban kirobbant, a Londoni Bankközi Kamatlábat érintő ún. LIBOR-botrány irányította rá a szabályozóhatóságok figyelmét a referenciaként alkalmazott bankközi kamatlábak sérülékenységére. A pénzügyi válság kapcsán kibontakozó szabályozási hullám alól így a referenciamutatók integritásának erősítése sem maradhatott ki.

Jelen tanulmány célja, hogy bemutassa, miként váltak a bankközi kamatlábak a gazdaság és a pénzügyi világ világítótornyaivá, továbbá hogy a Budapesti Bankközi Forint Hitelkamatláb (a továbbiakban: BUBOR) példáján keresztül értékelje azoknak a módszereknek a gyakorlati alkalmazhatóságát, amelyekkel a referenciamutatóként használt bankközi kamatlábak manipulációjára irányuló kísérletek visszaszoríthatók, illetve feltárhatók. Vitaindítóként bemutatásra kerül továbbá egy fizetési rendszeren alapuló modell is, amely jelentős mértékben eliminálni tudná a referenciamutató előállítása kapcsán jelentkező manipulációs kockázatot.

A tanulmány első felében a bankközi kamatlábak kialakulásának folyamatát írja le a LIBOR példáján. A bankközi kamatláb manipulációs potenciáljának meghatározására kidolgozott eljárást, illetve azokat a módszereket, amelyekkel a manipulációs potenciált mérsékelni, illetve bekövetkezés esetén felderíteni lehet, a második szerkezeti rész tartalmazza. Ezt követően a BUBOR példáján láthatjuk a bemutatott módszerek gyakorlati alkalmazhatóságát és hatékonyságát. A tanulmányt a következtetések ismertetése zárja.

\section{A bankközi kamatlábak és a manipulációs ösztönzők}

A bankközi kamatlábak manipulációs ösztönzőinek megértéséhez fontos megismerni, hogy milyen körülmények vezettek a kialakulásukhoz és milyen célt szolgáltak eredetileg. Jelen fejezet ezért a témát történelmi kontextusba helyezve mutatja be.

\subsection{A referenciaként használt bankközi kamatlábak kialakulása}

A második világháború lezárása utáni években, elsősorban a Marshall-terv keretein belül jelentős tőke (közel 12 milliárd amerikai dollár) áramlott az Egyesült Államok felől a (nyugat-) európai országok felé (Tarján 2018), amely megalapozta dinami- 
kusnak tekinthető fejlődési pályájukat. Az 1960-as évek elejére a nyugat-európai és észak-amerikai bankszektorban likviditás-bőség alakult ki, ami lehetőséget kínált a bankszektor számára, hogy a kockázatosnak tekinthető külföldi befektetések felé forduljon. A növekvő kereskedelem és az imént említett likviditásbőség mellett fontos indikátora volt a nemzetközi irányú tőkeáramlásnak az is, hogy Európában beindult a dollár alapú hitelezés, amely kívül esett egyfelől az Egyesült Államokban, másfelől pedig az Európában alkalmazott szabályozói rezsimeken. Az eurodollár-piacon a kamatszedést (kamatmentes betétek formájában) lényegében nem korlátozták, továbbá nem volt maximálva az alkalmazott kamatszint sem (Altunbas et al. 2006).

Az eurodollár-piac kialakulása, valamint a Bretton Woods-i rendszer biztosította valuták közötti viszonylagos árstabilitás (Borszéki 2009) együttesen remek táptalajul szolgáltak a nemzetközi magánbefektetésekhez. A nemzetköziesedés ugyanakkor többletkockázatot is rejtett magában. Ennek a kockázatnak a mérséklésére jöttek létre az ún. szindikált hitelek. A szindikált hitelezés során a többletlikviditással rendelkező bankok úgy tudtak külföldi entitásoknak hitelt nyújtani (többnyire külföldi bankoknak), hogy közben mérsékelték egyfelől a saját kockázatukat, másfelől pedig a hitelnyújtás kapcsán jelentkező költségeiket. A szindikált hitelezés során egy bank (administrative agent) van kijelölve arra, hogy összegyűjtse a forrásokat, és rá hárulnak a hitellel járó adminisztratív feladatok is. A hitelezés költségei és kockázatai így megoszlanak a hitelezők között, továbbá olyan kisebb hitelezők is bekapcsolódhatnak, amelyek erre nem lettek volna képesek önerőből. A visszafizetés kockázatát tovább csökkentette, ha a szindikált hiteladminisztrátor intézmény szerepét betöltő bank székhelye szerinti országnak szoros gazdasági kapcsolatai voltak a hitelfelvevő országával, tekintve, hogy a visszafizetés politikai kockázata is alacsonyabb volt ebben az esetben. A szindikált hitelek előnye nemcsak a hitelezőknél jelentkezett, hanem a hitelt felvevőknél is, mivel nem egy hitelező határozta meg a hitel költségszintjét (Gadanecz 2004; Altunbas et al. 2006; Gyntelberg - Wooldridge 2008; Ridley-Jones 2012).

A szindikált hitelezés népszerű volt mind a hitelezők, mind pedig a hitelezettek körében, így a piac mérete és a szindikált hitelek volumene is dinamikusan nőtt (Altunbas et al. 2006), ami a szindikált hitelezésben érintett bankok közötti kapcsolatokat is elmélyítette.

Ami a szindikált hitel árazását illeti, alapvetően háromfajta elemből tevődött össze. Voltak az úgynevezett állandó díjak, mint például a jogi és adminisztrációs költségek és a hitelt nyújtó bankok forrásszerzési költsége, valamint az erre rátevődött profit elem (Gadanecz 2004; Ridley és Jones 2012).

A gyakorlatban a hitelezők röviddel a hitelezés előtt - az adminisztrátor banknak fizetendő állandó díjak ismeretében - jelezték hitelnyújtási szándékukat és az adott 
tranzakcióhoz tartozó forrásköltségüket az adminisztrátor banknak. Ezeknek a költségeknek a volumennel súlyozott átlaga, illetve a súlyozott átlagra rátevődő profit (spread) adta meg végül, hogy milyen áron (kamatszint) nyújtják a szindikált hitelt. Tulajdonképpen a szindikált hitelezésben részt vevő bankok forrásköltségeinek súlyozott átlagát nevezték először LIBOR-nak, vagyis Londoni Bankközi Kamatlábnak.

Ez a rendszer eleinte a súlyozott átlag miatt nem ösztönözte az alacsony kamatszintet, ugyanis ha valamely résztvevő a többieknél lényegesen alacsonyabb forrásköltséget jelentett le, azt csak a többi bank kárára tehette, így ebben az esetben kizárták a hitelezők közül (Ridley és Jones 2012). Felülről nem volt korlátozva a kamatszint (pontosabban a piaci kereslet szabott csak korlátot). A kamatokat három, illetve hathavonta felülvizsgálták.

A LIBOR előállítását 1986-ban az Egyesült Királyság Bankszövetsége vette át BBALibor néven (British Bank Association London Interbank Offered Rate). A célja az volt, hogy a jegyzési folyamatot a szabályozottság és transzparencia növelésén keresztül intézményesítsék (Ridley - Jones 2012). Ennek eredményeként lett a LIBOR nyilvánosan elérhető és széles körben használt referenciamutató (benchmark).

\subsection{A manipulációs ösztönzők megjelenése}

A szindikált hitelezés beindulásával párhuzamosan a bankok igyekeztek a saját eszközeik lehető legnagyobb részét is ilyen módon befektetni, hiszen a szindikált hitelezésen keresztül nagyobb jövedelemre tudtak szert tenni, mintha ugyanazt az összeget a saját országukban, a vonatkozó (jövedelmet korlátozó) szabályozással összhangban, a hitelezés teljes kockázatával és költségével helyezték volna ki. Másképpen megfogalmazva, a saját tőke jövedelmezőségét maximalizálták, ami profitorientált szervezetek esetében érthető, illetve szükségszerű. Ami a banki múködés finanszírozását illeti, azt egyre inkább olcsó külső (leginkább hazai) forrásból biztosították. Így kialakult az a helyzet, hogy a bankot a likviditásbőségnek köszönhetően olcsó hazai forrásból múködtették, míg a külföldre irányuló szindikált hitelezésen keresztül a saját tőkén a korábbiaknál magasabb hozamot tudtak realizálni. A szindikált hitelek felvevőpiaca természetesen lényegesen nagyobb keresletet támasztott, mint amennyit a bankok kínálni tudtak. Ez a helyzet tovább növelte a szindikált hitelezés népszerüségét, tekintve, hogy annak jövedelmezősége stabilan magas maradhatott. Minél inkább külső forrásból finanszírozták saját működésüket a bankok, annál inkább érdekeltek voltak abban, hogy a forrásköltségük alacsony szinten maradjon. Ez a folyamat adta meg végső soron az ösztönzést arra is, hogy a LIBOR értékét a lehető legalacsonyabb szinten tartsák (Ridley és Jones 2012).

A manipulációs ösztönzők egy másik szálát a pénzügyi termékek innovációja jelentette. Az 1970-as évek végére a világgazdaság túl volt két olajválságon, illetve a dollár-sztenderd rendszer is rég a múlté volt, így nemzetközi viszonylatban a kockázatok is átalakultak - az olajárak emelkedése inflációt generált, aminek kapcsán a kamat-, 
illetve az árfolyamkockázat a korábbinál jelentősebbé vált. Az imént említett kockázatok mérséklésére fejlesztették ki a kamat swap ügyletet (IRS ${ }^{1}$ ) és a határidős kamatláb-megállapodást $\left(\right.$ FRA $\left.^{2}\right)$.

Az első IRS-ügyletet 1981-ben, míg az első FRA-ügyletet 1983-ban kötötték (Kuprianov 1993; Farkas et al. 2004; Gyntelberg - Wooldridge 2008). Mind a két ügylettípus esetében fontos szerepet játszik a változó kamatláb, ugyanis ennek függvényében nyer, illetve veszít az ügyleten annak megkötője. A változó kamatlábat kezdetben különféle indexek reprezentálták, amelyeket 1986-os hivatalossá tétele után fokozatosan a LIBOR váltott fel. Ezzel gyakorlatilag egyfelől a LIBOR vált a legjelentősebb referenciamutatóvá, másfelől pedig, a továbbiakban az IRS- és FRA-ügyletek kitüntetett időpontjai ${ }^{3}$ is manipulációs ösztönzőt jelentettek. A teljes kép kedvéért szükséges megemlíteni, hogy a LIBOR mellett más jelentős bankközi kamatlábak is voltak, de a LIBOR volt közülük a legismertebb és leginkább elfogadott.

Végül, de nem utolsó sorban meg kell említeni azt is, hogy a kamatkockázat kapcsán egyre több pénzügyi termék árazása kötődött, illetve kötődik jelenleg is a bankközi kamatlábak alakulásához (pl. jelzáloghitelek és vállalati hitelek kamatszintje), ami az imént említett derivatív ügyletekhez hasonlóan további manipulációs ösztönzőt jelentett a bankközi kamatlábak (így a LIBOR) vonatkozásában.

\subsection{A LIBOR manipulációja és a visszaszorítására tett intézkedések - a szabályozói környezet}

A referenciamutatóként használt bankközi kamatlábak 2007-ben kerültek a szabályozó hatóságok látóterébe a LIBOR-t érintő manipulációs botrány kapcsán, ugyanis ekkor jelentette a Barclays az Egyesült Államok pénzpiaci felügyeleténél, hogy véleménye szerint egyes bankok manipulálhatják a Londoni Bankközi Kamatláb, vagyis a LIBOR értékét (Cutler - Ridley 2013). A manipuláció oly módon történt, hogy a valósnál alacsonyabb értéket jelentettek le bizonyos, a LIBOR jegyzésében részt vevő bankok. A nemzetközi szintű botrány ugyanakkor csak 2008-ban pattant ki a The Wall Street Journal-ban megjelent leleplező cikk kapcsán (Mollencamp 2008). A LIBOR-botrány eredőjeként elrendelt vizsgálatok megállapították, hogy a LIBOR manipulációja egészen 1991-ig vezethető vissza, vagyis ekkortól rendszeresen manipulálta a LIBOR értékét a manipulációban érintett 11 bank (Fliszár 2016; Cutler-Ridley 2013; Mollencamp 2008).

A manipuláció visszaszorítása érdekében az Értékpapírpiaci Felügyeletek Nemzetközi Szervezete (a továbbiakban $\mathrm{IOSCO}^{4}$ ) 2013 júliusában jelentette meg a pénzügyi

\footnotetext{
${ }^{1}$ Interest Rate Swap

${ }^{2}$ Forward Rate Agreement

${ }^{3}$ Azon napok, amikor az aktuális kamatszint szerint megtörténik az elszámolás az ügyletet megkötő felek között.

${ }^{4}$ International Organization of Securities Commissions
} 
referenciamutatókra (vagy másképpen pénzügyi benchmarkokra) vonatkozó ajánlásait (IOSCO 2013). Ezek elsősorban a referencia előállítója számára határoznak meg követendő javaslatokat, de közvetett módon a referenciamutatóhoz adatot szolgáltató intézményeket is érintik. Az összesen 19 ajánlás alapvetően három területet céloz az alábbiak szerint:

1. A referenciamutató előállításához használt adatok megfelelősségének biztosítása.

2. A referenciamutató előállítási módszertanának megfelelősége, illetve transzparenciája.

3. Összeférhetetlenségi helyzetek azonosítása és felszámolása (érdekkonfliktusok), valamint megfelelő kontrollok alkalmazása.

Mind a három cél a referenciamutatók megbízhatóságát hivatott megteremteni (visszaállítani).

Az Európai Unióban 2016. június 8-án lépett hatályba az ún. Benchmark rendelet ${ }^{5}$ (a továbbiakban: BMR), amely jogszabályba ültette át a referenciamutató-képzéssel kapcsolatos elvárásokat. A BMR előírásai közvetlenül alkalmazandók az európai uniós tagországokban a referenciamutató képzéséért felelős intézmények (administrator), valamint a jegyzésben résztvevő intézmények (contributor) számára.

\section{Módszerek a referenciamutatóként alkalmazott bankközi kamatláb-jegyzés manipulációjának megelőzésére, valamint feltárására}

A BMR-rendelet számos olyan előírást tartalmaz, amely a referenciamutatóként alkalmazott bankközi kamatláb jegyzésének megbízhatóságát és egyben a manipulációjára vonatkozó ösztönzőket igyekszik visszaszorítani. Ilyennek tekinthető többek között az az elvárás, hogy a jegyzésben részt vevő (referenciakamat-jegyző és -jóváhagyó) munkatársak külső és belső kommunikációját a jegyzésben részt vevő intézmény köteles rögzíteni és visszakereshető módon megőrizni. Ugyanakkor bármilyen szigorú előírásokat tehet a jogalkotó, azok teljes mértékben sosem fogják garantálni a jegyzések manipulációmentességét, csupán növelik a manipulációs szándék potenciális költségét. Az intézményi hivatalos kommunikáció rögzítése esetében kibúvó lehet például a munkavállaló saját telefonján folytatott beszélgetés, valamint az ebédszünetekben tartott informális megbeszélés is. Figyelembe véve, hogy az ellenőrzésnek is költsége van, amelynek racionális szinten kell maradnia,

\footnotetext{
${ }^{5}$ Az Európai Parlament és a Tanács (EU) 2016/1011 rendelete (2016. június 8.) a pénzügyi eszközökben és pénzügyi ügyletekben referenciamutatóként vagy a befektetési alapok teljesítményének méréséhez felhasznált indexekről, valamint a 2008/48/EK és a 2014/17/EU irányelv, továbbá az 596/2014/EU rendelet módosításáról.
} 
inkább olyan módszerek felé érdemes fordulni, amelyek nagy valószínűséggel megelőzik, illetve jelzik a referenciamutató manipulálásának gyanúját. Ezzel gyakorlatilag megakadályozhatjuk azt, hogy a védelmi vonalak szükségtelen hosszúságú láncolatát alkossuk meg.

Fontos ugyanakkor már az elején leszögezni, hogy minden bemutatásra kerülő módszer - függetlenül attól, hogy az a szakirodalom alapján adaptált, vagy a tanulmány szerzőjének saját gondolatait tükrözik - csak a manipuláció gyanújának jelzésére, illetve bekövetkezési valószínűségének mérséklésére alkalmasak, tekintve, hogy a referenciamutatóként használt bankközi kamatláb jegyzési folyamatában részt vevő bankok likviditási helyzete, stratégiai célkitűzéseik, valamint az alkalmazott monetáris politikai eszközök hatással lehetnek, illetve vannak is a referenciamutató értékének alakulására (Gereben 2000).

Az alábbiakban a módszerek attól függetlenül kerülnek bemutatásra, hogy azokat a referenciamutató elóállítója, a referenciamutatóhoz adatot szolgáltató intézmény, vagy éppen a külső ellenőrzést végző szervezet alkalmazza.

\subsection{A manipulációs potenciál definíciója}

Eisl és szerzőtársai (2017) tanulmányukban a referenciakamatként használt bankközi kamatláb manipulációs potenciálját oly módon vizsgálták, hogy a LIBOR tárgynapi jegyzései közül a legkisebb jegyzés értékét egyenlővé tették a legnagyobb jegyzés értékével. Ezzel azt a helyzetet modellezték, hogy egyetlen jegyző bank, ha manipulálni szeretné a referenciamutató értékét, milyen mértékben lenne képes elmozgatni azt. Az eredeti LIBOR és a módosított LIBOR értéke közötti különbség adta a manipulációs potenciál értékét. Jelen tanulmány keretein belül az Eisl és szerzőtársai (2017) által alkotott modell került adaptálásra eltérő szcenáriók mentén.

\subsection{Trimmelt átlag (nyesési eljárás)}

A LIBOR értékét kezdetben a szindikált hitelezésben résztvevők forrásköltségének és az általuk nyújtott hitel nagyságának súlyozott átlaga adta. A LIBOR 1986-os hivatalossá tételétől kezdődően nem volt bázisa a súlyozásnak, így az a módszertanból kikerült és a lejelentett értékek számtani átlaga adta meg végül a bankközi kamatláb értékét. Az egyszerú számtani átlag módszertani hibája ugyanakkor, hogy rendkívül érzékeny a kiugró értékekre. A gyakorlatban ez azt jelenti, hogy már egy bank is képes befolyásolni, akár jelentős mértékben is, a referenciaként alkalmazott bankközi kamatláb értékét.

Ennek a kiküszöbölésére alkalmazzák az ún. trimmelést, vagy másképpen nyesési eljárást. A módszer lényege, hogy az átlagot leginkább „elhúzó" legnagyobb és legkisebb jegyzéseket (vagy a jegyzések bizonyos százalékát) kihagyják az átlagszámításból, és az ilyen módon képzett átlag lesz végül a hivatalos bankközi referenciamutató értéke. 
Eisl és szerzőtársai (2017) tanulmányukban a trimmelt átlag hatékonyságát vizsgálták. Arra voltak kíváncsiak, hogy az ún. aluljegyzés (amikor a bank által beadott fixing az átlag, vagyis a bankközi kamatláb alatt van) milyen mértékben képes elmozdítani a bankközi kamatláb értékét. Kimutatták, hogy a nyesési eljárás ugyan lényegesen javítja a referenciamutató értékének megbízhatóságát, ugyanakkor egyetlen jegyzésben részt vevő bank is, a trimmelt átlag mellett is el tudja mozgatni a bankközi referenciamutatót - a számításuk alapján az eltérítés mértéke a 3 havi USD LIBOR esetében 0,48 bázispont, míg a 3 havi EURIBOR esetében 0,17 bázispont volt. Ez az érték progresszíven nőtt, amikor több bank jegyzését összehangoltan módosították. Következtetésük alapján minél több intézmény vesz részt a referencia-kamatláb jegyzési eljárásában, annál kisebb a manipulációs potenciál. A Choy és szerzőtársai (2012) által készített tanulmány alátámasztja a fentieket, vagyis egyetlen bank is képes befolyásolni a referenciamutató értékét a nyesési eljárás ellenére is.

Eisl és szerzőtársainak (2017) ellenőrzési szempontból kiemelt megállapítása, hogy az egyes intézmények alul-, illetve felüljegyzése folyamatosan változik, így a manipuláció azonnali detektálása nem lehetséges.

\subsection{Medián-jegyzés}

A medián-jegyzés során a kamatjegyzésben részt vevő intézmények (bankok) megküldik a jegyzést végző adminisztrátor-intézménynek a szükséges adatokat (fixingeket). Ezeket a jegyzést végző intézmény növekvő sorba állítja. A referenciamutató értéke ebben az esetben a medián szerepét betöltő jegyzés lesz, vagyis az, amelyik a sorba rendezett adatokat két egyenlő részre bontja (páros számú jegyző bank esetén a két középső elem (fixing) egyszerű számtani átlaga adja a referenciamutató értékét).

Eisl és szerzőtársai (2017) elemzése kimutatta, hogy a medián alapú jegyzés minimális szintre csökkenti a manipulációs potenciált (a trimmelt átlag kapcsán bemutatott érték harmadára).

\subsection{Dinamikus szélsőérték-elemzés}

A dinamikus szélsőérték-elemzés során az aktuális, illetve az előző nap jegyzései közötti abszolút különbséget vizsgáljuk. Azoknak a jegyző intézményeknek a jegyzéseit, amelyek az előző napihoz képest leginkább változtak abszolút értéken (pozitív vagy negatív irányba), nem vesszük figyelembe a referenciamutató képzésekor. Ebben a tekintetben a dinamikus szélsőérték alapján képzett referenciamutató is egyfajta trimmelt átlagnak feleltethető meg.

A módszer előnye lehet, hogy kiszűri az egyszeri hatásokat és ezáltal a referenciamutató értéke kisimultabb képet fog mutatni az egyes napok között. Ilyen egyszeri hatásként lehet említeni például a jegyzéshez adatot szolgáltató intézmények hibáját, vagy éppen rendkívüli likviditási helyzetüket. 
Dinamikus szélsőérték-elemzés kapcsán csak úgy tud egy-egy adatszolgáltató manipulációt végrehajtani, ha folyamatosan abban az értékzónában tartja a jegyzéseit, amely neki megfelelő lehet adott napon. Ebben az esetben ugyanakkor a lebukás valószínúsége (vagy másképpen, a manipuláció tranzakciós költsége) is megnő.

\subsection{Korreláló termék árazásának elemzése}

Monticini - Thornton (2013) szerint a referenciamutatóként alkalmazott bankközi kamatláb manipulációja esetén a referenciamutató értéke és az azzal korreláló hozamú termék árazása között pozitív vagy negatív irányban eltérés lesz. Munkájukban a LIBOR és a letéti jegy (Certificate of Deposit - CD) hozamai közötti összefüggést vizsgálják. A szerzők elmélete szerint a LIBOR és a CD hozamai között az időben közel azonos eltérés áll fenn (bázispontban kifejezve), vagyis a kettő között a korrelációból adódóan kirajzolódik egy konstansnak tekinthető különbözet (spread), amelynek a szórása állandó. Amennyiben a LIBOR és a CD hozama közötti különbözet értéke szignifikánsan változik (a LIBOR és a CD hozamai közötti különbözet értékének idősorából számított átlagérték), úgy felmerül a referenciamutató manipulációjának gyanúja. Elemzésükben 2004 és 2010 közötti adatokat dolgoztak fel, amely alapján bebizonyosodott, hogy manipuláció esetén nőtt a különbség a LIBOR és a CD hozamai között, illetve az is, hogy a manipulációs tevékenység után a különbözet (spread) értéke visszatért a korábbi szintre. Brousseau és szerzőtársai (2009) az OIS (Overnight Index Swap) és LIBOR kapcsán jutnak hasonló következtetésre.

A módszer utólagos vizsgálatra alkalmas és fontos előfeltétele, hogy aktív piaca legyen a korreláló terméknek is.

\subsection{Kiugróérték-elemzés}

A kiugróérték-elemzés során két szempontot vizsgálhatunk. Egyfelől azt, hogy az egyes jegyzésben részt vevő intézmények jegyzései a saját korábbi jegyzéseik függvényében hogyan alakulnak, másfelől pedig azt, hogy a referenciamutató alakulásának függvényében hogyan alakulnak. Amennyiben a tárgynapi és bázisnapi jegyzés között az eltérés egy bizonyos szintet meghalad, mindkét esetben fennáll a manipuláció vagy a hiba gyanúja, így az aznapi jegyzés értékét érdemes kivizsgálni.

Az eltérés mértékét, amelynek meghaladása az imént említett intézkedés kiváltását indukálja, többféle megközelítésben lehetséges meghatározni. Első és talán legegyszerúbb eljárás, ha meghatározunk egy előre definiált időtávot, amelyet figyelembe veszünk a szórásszámítás szempontjából (intézményi saját jegyzés, illetve a referenciamutató szórásának számítását tekintve). Amennyiben a tárgynapi különbözet abszolút értéken meghaladja a szórás értékét vagy annak kétszeresét, kiugró értékként tekinthetünk a tárgynapi jegyzésre. Ilyen módon minden nap meg kell határozni az azonos hosszúságú időszakra (visszatekintési idő) vonatkozó szórást és ahhoz kell hasonlítani a tárgynapi jegyzés értékét. 
Kevésbé dinamikus megoldás, ha hosszabb idősor (pl. 10 év) alapján határozzuk meg a szórás értékét. Ennek előnye, hogy a számításban nagy valószínűség szerint szerepel stresszes és stresszmentes időszak is, valamint a kamatkörnyezet emelkedése és csökkenése is. Hosszabb idősor esetén a nagyobb szórásérték miatt célszerü a szórás értékének tört részéhez viszonyítani a változás mértékét.

Szofisztikáltabb módszer, ha meghatározzuk azt, hogy a jegyzések hány százalékát szeretnénk közelebbről megvizsgálni. Ebben az esetben a múltbeli adatok alapján meg lehet határozni úgy egy jegyzés értékváltozásának mértékét, hogy az esetek egy bizonyos, előre meghatározott százaléka (amelyet ellenőrizni akarunk) beleessen. A kifinomultsága ellenére az utóbbi módszer hátránya, hogy kevésbé szolgál a manipulációs gyanú indikátoraként, tekintve, hogy olyan esetek is beleeshetnek, amelyeknél a változás mértéke a két nap jegyzése között nem jelentős.

Közös ezekben a módszerekben, hogy megfelelő módon kell kiválasztani a visszatekintési periódust, vagyis azt az időszakot, amelyet figyelembe veszünk a számítások során. Ezért az itt bemutatott módszerek alkalmazása előtt szükséges ennek kalibrálása.

\subsection{Az alul- és felüljegyzések dinamikájának vizsgálata}

Az alul és felüljegyzések dinamikájának elemzésekor azt vizsgáljuk, hogy adott jegyző milyen mértékben adott olyan jegyzést, amely végül a referenciamutató napi értéke alatt vagy felett helyezkedett el. A kamatjegyző bankok közötti különbségek miatt kialakulhatnak jellemzően alul-, illetve jellemzően felüljegyző bankok. Természetesen ez nem azt jelenti, hogy rövidebb időtávon belül ez minden esetben érvényesül, így a jegyzések dinamikáját elemezve az egyes mintázatok alapján lehetséges a jegyzés manipulációjára utaló jeleket azonosítani. Ebben a tekintetben ez a módszer kevésbé objektív, ugyanakkor más módszertanokkal együtt alkalmazva hatékony eszköze lehet a jegyzés manipulációjának jelzésére, illetve a felmerült gyanú alátámasztására. Az alul és felüljegyzések dinamikájának elemzése az előzőeken túl információt szolgáltat arról is, hogy milyen módon alakul a jegyzésben részt vevő intézmények likviditása, valamint arról is, hogy a likviditás milyen mértékben koncentrálódik a piacon.

\subsection{Kitüntetett napok vizsgálata}

A referenciamutatóként alkalmazott bankközi kamatláb manipulálása kapcsán a legnagyobb kockázatot azok a kitüntetett napok hordozzák, amikor a derivatív ügyletek kapcsán elszámolási tevékenység történik, ha a jegyzésben részt vevő munkatárs egyben derivatív ügyleteket is köthet, tekintve, hogy a jegyzés révén befolyásolni tudja az általa kötött ügyletek eredményét (jövedelmezőségét). Az ügyletkötésben érintett derivatív ügyletkötő manipulációs kockázatát csökkenti, ha az ügyletkötésben partnerintézmény szintén részt vesz a referenciaként alkalmazott bankközi kamatláb jegyzési folyamatában, tekintve, hogy ő ellenérdekelt lesz. A kockázat 
azonban abban az esetben fokozottan jelentkezik, ha a derivatív ügyletet a jegyzési folyamatban nem érintett féllel kötik a jegyzésben résztvevő ügyletkötők.

Az előzőeken túlmenően azok a napok is közvetetten kockázatot hordoznak, amikor a jegyzésben részt vevő banknál jelentős mértékű eszközátárazódás történik a bankközi kamatláb alapján. Ilyen eset lehet például, ha a banki vagy több bank összes lakáshitelének vagy vállalati hitelének kamata ugyanazon a napon (pl.: hónap vége előtti 2. munkanapon ${ }^{6}$ ) érvényes bankközi kamatláb alapján árazódik újra.

A módszer lényege a fentiek alapján, hogy azoknak a napoknak a jegyzéseit szükséges vizsgálni, amikor a derivatív ügyletek kapcsán elszámolási tevékenység történik, illetve, amikor jelentős mértékű eszközátárazódás megy végbe.

Fontos megjegyezni és hangsúlyosan kiemelni, hogy önmagában az, hogy egy bank felül- vagy aluljegyez egy ilyen kitüntetett napon, nem jelenti automatikusan azt, hogy manipulál, tekintve, hogy a bank likviditási helyzete, az érvényben lévő monetáris politikai eszközök, valamint a piaci sajátosságok hatással vannak a jegyzésekre is. Ezért a kitüntetett napokon történő jegyzést csak és kizárólag utólagosan, idősor alapján és tendenciáiban érdemes vizsgálni.

Jelen tanulmány keretein belül ez a módszer nem kerül a fentiekben megfogalmazottakon túl kifejtésre, mivel az alkalmazásához szükséges adatok nyilvánosan nem érhetőek el.

\subsection{Az együttjegyzések elemzése}

Choy és szerzőtársai (2012) azt vizsgálták, hogy lehetséges-e többváltozós statisztikai módszer alkalmazásával feltárni a manipulációt, illetve a bankok közötti összejátszást. Tanulmányukban hierarchikus klaszteranalízissel, 2005 és 2012 közötti LIBOR adatok felhasználásával sikerült kimutatniuk, hogyha egy bank jegyzései a többi bank jegyzésétől szignifikánsan eltértek (vagyis nem valós forrásköltséget jelentett le). Nézetük szerint egy jól összehangolt (több bankot érintő) bankközi manipuláció feltárására is alkalmas lehet a módszer. Összehangolt manipuláció esetén az összejátszó bankokat ugyanis a klaszterelemzés egy csoportba sorolja. A szerzőpáros felhívja a figyelmet arra is, hogy a klaszterelemzés eredményeit szemléltető dendrogram alapján (csoportok) végleges következtetést levonni nem szabad - a manipuláció gyanúját ugyanakkor jelzi. Sajtos - Mitev (2007) megfogalmazása alátámasztja azt, miszerint a klaszterelemzés elsősorban feltáró technika.

A gyakorlatban érdemes két vagy több különböző távolságmérési és hasonlósági mértéken alapuló klaszterelemzéssel elvégezni a csoportképzést. Amennyiben sta-

\footnotetext{
${ }^{6}$ A 2009. évi CLXII. törvény (Fairbank törvény) 17/D.§ (1) bekezdése alapján a referencia-kamatlábhoz kötött kamatozású hitelszerződés esetén a referencia-kamatláb mértékét a hitelszerződésben meghatározott referenciakamat futamidejének megfelelő időközönként kell a fordulónapot megelőző hónap utolsó munkanapja előtt 2 nappal érvényes referencia-kamatlábhoz igazítani.
} 
bilan együttjegyez két jegyzésben részt vevő intézmény, úgy a két eltérő technika közel azonos eredményt fog adni. Ez esetben az összejátszás (manipuláció) gyanúja fennállhat, így további vizsgálatok szükségesek.

A módszertan hátránya, hogy csak teljes idősorokra alkalmazható, így, amennyiben egy jegyző bank a mért időszakon belül jelenik meg, vagy éppen lép ki a jegyzők közül (vagyis nincs teljes adatsor az érintett intézmény esetében), azt ki kell zárni a vizsgálatból. A módszer továbbá érzékeny a kiugró értékekre, így azokat valamilyen eljárással szükséges kezelni az elemzés elvégzése előtt.

\subsection{Fizetésirendszer-üzemeltetők mint referenciamutató adminisztrátorok}

Új megközelítés a referenciamutatóként használt kamatláb fizetési rendszeren keresztül történő meghatározása. Feltételezve, hogy a bankközi kamatlábak számítása a bankközi fedezetlen hitelek alapján történik, a nagy értékű fizetési rendszereken keresztül végrehajtott tényleges tranzakciók felhasználásával rendelkezésre áll a referenciakamat előállításához szükséges információ, így a fizetési rendszer üzemeltetője láthatja el a referenciamutató adminisztrátor szerepét. Az Európai Központi Bank esetében ilyen az ESTER (Euro Short-Term Rate) referenciamutató (ECB 2018), amely a TARGET2 nagy értékű fizetési rendszer adatain alapul. Ettől némiképp eltérő megközelítést javasolt Frost (2017) az Egyesült Államokban a SOFR (Secured Overnight Financing Rate) referenciamutató kapcsán. A különbség az, hogy a referenciamutató képzéséhez szükséges adatokat adattárházból, nem pedig a fizetési rendszeren keresztül szerezné be.

Ebben a kontextusban a manipulációs ösztönző a banki oldalon megszűnik, mivel a tényleges tranzakciók alapján határozzák meg a bankközi kamatláb mértékét. $A$ társadalmi optimum szempontjából így jelentősen csökkenhet az az erőforrás-menynyiség, amelyet jelenleg a piaci résztvevők és maguk a felügyeleti szervek is arra használnak, hogy ellenőrizzék a jegyzések integritását, illetve piackonformitását.

\section{BUBOR}

Ebben a részben a Budapesti Bankközi Forint Hitelkamatláb, vagyis a BUBOR példáján keresztül mutatjuk be az előző fejezetben részletesen tárgyalt azon módszereket, amelyekhez elegendő nyilvánosan elérhető adat állt rendelkezésre.

\subsection{Vizsgált tenorok}

A tanulmány írásakor a BUBOR-jegyzés adminisztrátori szerepét betöltő Magyar Nemzeti Bank (MNB) kilenc tenor (lejárat) kapcsán publikál hivatalos BUBOR-értéket (overnight ${ }^{7}, 1$ hét, 2 hét, 1 hónap, 2 hónap, 3 hónap, 6 hónap, 9 hónap és 1 év). Ezek közül jelen cikk keretein belül terjedelmi korlátok okán az overnight jegyzésekkel

${ }^{7} \mathrm{O} / \mathrm{N}$ 
foglalkozunk, ugyanakkor az alkalmazott módszertanok az összes tenorra vonatkozóan alkalmazhatóak, így például a 3 és 6 hónapos tenorokra is ${ }^{8}$.

\subsection{Vizsgált időszak}

A REUTERS-en keresztül elérhető BUBOR-idősor 2014 januárjától 2018. augusztus 15-ig állt rendelkezésre a tanulmány írásakor, így ezen időszak teljes mértékben feldolgozásra került. Ezen belül két időszakot érdemes külön vizsgálni, tekintve, hogy 2017 elejétől a nulla közeli kamatkörnyezet kapcsán a BUBOR-jegyzések szórása jelentősen csökkent a korábbi időszakhoz képest. A két időszak így a 2017 előtti és utáni időszak (1. ábra).

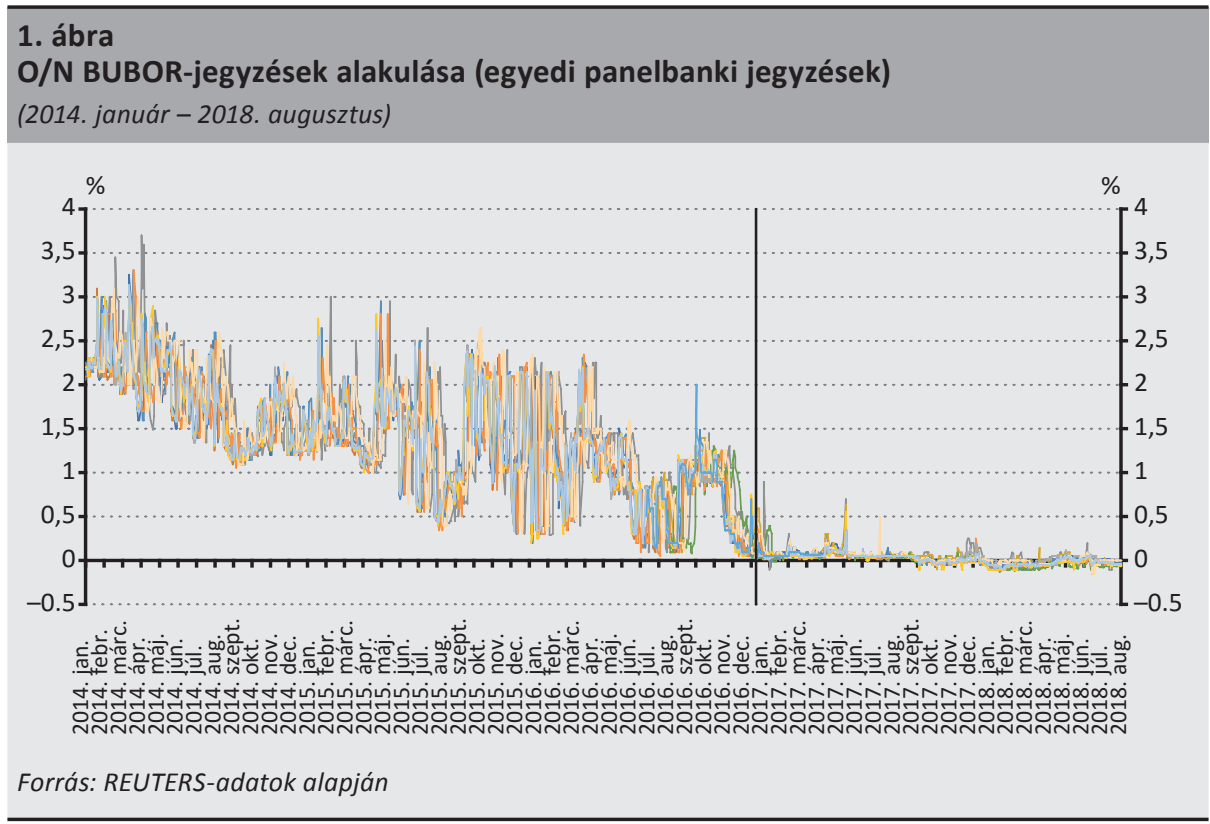

\section{3. Átlag-, medián-, trimmelt átlag- és trimmelt medián-jegyzés}

Eisl és szerzőtársai (2017) munkája alapján a BUBOR esetében is megvizsgáltuk, hogy mekkora az egynapos fedezetlen bankközi hitel (overnight) jegyzések esetében a bankközi kamatláb manipulációs potenciálja. A vizsgálat keretrendszere ugyanakkor kiegészítésre került, így nem csak az aluljegyzési, hanem a felüljegyzési potenciál is a vizsgálat tárgyát képezte. Az aluljegyzési, illetve a felüljegyzési potenciál így összesen a két elkülönült időszakra, időszakonként 6-6 szcenárió mentén került megállapításra az alábbiak szerint:

${ }^{8}$ Kocsis et al. (2013) tanulmánya szerint a kamatderivatíva-piacon a 3 és 6 hónapos tenoroknak van kitüntetett szerepe. 
- három bank összejátszása a felüljegyzésre;

- két bank összejátszása a felüljegyzésre;

- egy bank felüljegyzése;

- egy bank aluljegyzése;

- két bank összejátszása az aluljegyzésre;

- három bank összejátszása az aluljegyzésre.

A felvázolt szcenáriók mentén kiszámításra került a jegyzések átlaga, mediánja, trimmelt átlaga, és trimmelt mediánja. A trimmelés (vagy nyesés) a 2018. január 1-jétől hatályos BUBOR-szabályzat alapján történt (MNB 2018). Ez alapján annál jobban teljesített egy módszer, minél kisebb mértékben módosította átlagosan a manipuláció az eredetileg kiszámított eredményt. Az 1. táblázat összefoglalva tartalmazza a vizsgálat eredményét.

\section{1. táblázat}

Az O/N BUBOR manipulációs potenciálja az alkalmazott módszerek szerint

\begin{tabular}{|c|c|c|c|c|c|c|c|c|}
\hline \multirow{3}{*}{$\begin{array}{l}\text { BUBOR O/N } \\
\text { manipulá- } \\
\text { ciós } \\
\text { potenciál }\end{array}$} & \multicolumn{4}{|c|}{ Nagy jegyzési volatilitás } & \multicolumn{4}{|c|}{ Alacsony jegyzési volatilitás } \\
\hline & \multicolumn{2}{|c|}{ Eltérés (bp) } & \multicolumn{2}{|c|}{ Módszer neve } & \multicolumn{2}{|c|}{ Eltérés (bp) } & \multicolumn{2}{|c|}{ Módszer neve } \\
\hline & $\min$ & $\max$ & legjobb & legrosszabb & $\min$ & $\max$ & legjobb & legrosszabb \\
\hline $\begin{array}{l}\text { Felüljegyzés } \\
\text { (3 bank) }\end{array}$ & $-9,64$ & $-12,70$ & $\begin{array}{l}\text { Trimmelt } \\
\text { medián }\end{array}$ & Átlag & $-0,02$ & $-2,06$ & Átlag & $\begin{array}{l}\text { Trimmelt } \\
\text { medián }\end{array}$ \\
\hline $\begin{array}{l}\text { Felüljegyzés } \\
\text { ( } 2 \text { bank) }\end{array}$ & $-5,46$ & $-10,09$ & $\begin{array}{l}\text { Trimmelt } \\
\text { medián }\end{array}$ & Átlag & $-0,01$ & $-1,21$ & Átlag & $\begin{array}{l}\text { Trimmelt } \\
\text { medián }\end{array}$ \\
\hline $\begin{array}{l}\text { Felüljegyzés } \\
\text { (1 bank) }\end{array}$ & $-0,92$ & $-7,28$ & $\begin{array}{l}\text { Trimmelt } \\
\text { átlag }\end{array}$ & Átlag & $-0,01$ & $-0,63$ & Átlag & $\begin{array}{l}\text { Trimmelt } \\
\text { medián }\end{array}$ \\
\hline $\begin{array}{l}\text { Aluljegyzés } \\
\text { (1 bank) }\end{array}$ & 1,19 & 7,28 & $\begin{array}{l}\text { Trimmelt } \\
\text { medián }\end{array}$ & Átlag & 0,01 & 0,45 & Átlag & $\begin{array}{l}\text { Trimmelt } \\
\text { átlag }\end{array}$ \\
\hline $\begin{array}{l}\text { Aluljegyzés } \\
\text { ( } 2 \text { bank) }\end{array}$ & 10,08 & 13,77 & $\begin{array}{l}\text { Trimmelt } \\
\text { medián }\end{array}$ & $\begin{array}{l}\text { Trimmelt } \\
\text { átlag }\end{array}$ & 0,02 & 1,11 & Átlag & $\begin{array}{l}\text { Trimmelt } \\
\text { átlag }\end{array}$ \\
\hline $\begin{array}{l}\text { Aluljegyzés } \\
\text { (3 bank) }\end{array}$ & 18,16 & 25,27 & Átlag & $\begin{array}{l}\text { Trimmelt } \\
\text { átlag }\end{array}$ & 0,02 & 2,02 & Átlag & $\begin{array}{l}\text { Trimmelt } \\
\text { medián }\end{array}$ \\
\hline
\end{tabular}

Az 1. táblázat szerint akkor, amikor alacsony a jegyzések volatilitása, a legkisebb manipulációs potenciált a számtani átlag alapján történő számítás adja, míg a legnagyobb manipulációs potenciált a trimmelt medián és a trimmelt átlag eljárások eredményezik. Amikor a jegyzések volatilitása nagy, akkor viszont a trimmelt medián tűnik a legbiztosabb módszernek (legkisebb manipulációs potenciál) és a számtani átlag a legrosszabbnak (legnagyobb manipulációs potenciál). Eisl és szerzőtársai 
(2017) eredményeit kiegészítve elmondható, hogy volatilis időszakban (a fixingek megnövekedett szórása esetén) megnövekedik ez a manipulációs potenciál, míg kevésbé volatilis időszakban csökken.

A táblázatban szereplő értékek alapján az is látható, hogy míg alacsony jegyzési volatilitás mellett az alul-, illetve felüljegyzési manipulációs potenciál közel azonos minden szcenárió mentén, magas jegyzési volatilitású időszakban az aluljegyzési manipulációs potenciál magasabb. Ennek több oka lehet. Egyfelől tényezőként játszik közre a jegyző intézmények likviditási helyzete, valamint figyelembe kell venni a jegyző intézmények stratégiáit is. Például nem biztos, hogy célja egy-egy intézménynek, hogy fedezetlen bankközi piacra helyezze ki likviditását - ekkor felüljegyez, így a manipulációs potenciál mérésére használt módszertan szerint jobban lefele mozdul el a BUBOR értéke. Az összes megvizsgált szcenárió szerint számított manipulációs potenciált egy ábrán összegezve jól látható, hogy az aluljegyzési manipulációs potenciál a jelentősebb (2. ábra).

\section{2. ábra}

O/N BUBOR-jegyzések manipulációs potenciálja a jegyzések szórásának függvényében a vizsgált szcenáriók mentén

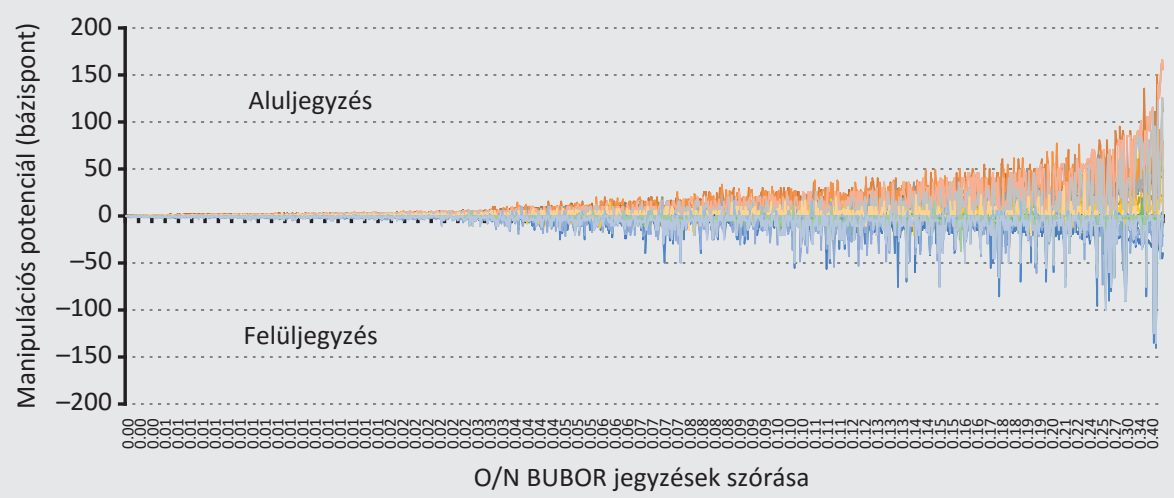

Megjegyzés: Az egyes színek az egyes szcenáriókat jelölik.

Végül, de nem utolsó sorban megállapítható, hogy a medián alapú jegyzés a manipulációs potenciált annál inkább képes csökkenteni, minél több azon intézményi jegyzések száma, amelyek a nyesési eljárás után a kalkulációs kosárban maradnak. Nincsen arra egzakt szám, hogy hány intézménynek kell részt vennie a jegyzésben ahhoz, hogy a manipulációs potenciál a minimum szintre csökkenjen medián típusú jegyzés esetén. A medián képzési módszertanából kiindulva ugyanakkor célszerű, ha a nyesési eljárás után minimum három intézmény jegyzése képezi a kiválasztás alapját - vagyis sorrendbe rendezve a középső érték adná meg végül a referenciamutató értékét. 


\subsection{Dinamikus szélsőérték-elemzés}

A dinamikus szélsőérték-elemzés önmagában megfeleltethető egy trimmelési eljárásnak, így itt csak két módszer került górcső alá, a dinamikusan képzett átlag és a dinamikusan képzett medián.

\begin{tabular}{|c|c|c|c|c|c|c|c|c|}
\hline \multicolumn{9}{|l|}{ 2. táblázat } \\
\hline \multirow{3}{*}{$\begin{array}{l}\text { BUBOR O/N } \\
\text { manipulá- } \\
\text { ciós } \\
\text { potenciál }\end{array}$} & \multicolumn{4}{|c|}{ Nagy jegyzési volatilitás } & \multicolumn{4}{|c|}{ Alacsony jegyzési volatilitás } \\
\hline & \multicolumn{2}{|c|}{ Eltérés (bp) } & \multicolumn{2}{|c|}{ Módszer neve } & \multicolumn{2}{|c|}{ Eltérés (bp) } & \multicolumn{2}{|c|}{ Módszer neve } \\
\hline & $\min$ & $\max$ & legjobb & legrosszabb & $\min$ & $\max$ & legjobb & legrosszabb \\
\hline $\begin{array}{l}\text { Felüljegyzés } \\
\text { (3 bank) }\end{array}$ & $-21,25$ & $-24,62$ & $\begin{array}{l}\text { Dinamikus } \\
\text { átlag }\end{array}$ & $\begin{array}{l}\text { Dinamikus } \\
\text { medián }\end{array}$ & $-0,02$ & $-2,18$ & $\begin{array}{l}\text { Dinamikus } \\
\text { átlag }\end{array}$ & $\begin{array}{l}\text { Dinamikus } \\
\text { medián }\end{array}$ \\
\hline $\begin{array}{l}\text { Felüljegyzés } \\
\text { ( } 2 \text { bank) }\end{array}$ & $-16,96$ & $-19,89$ & $\begin{array}{l}\text { Dinamikus } \\
\text { átlag }\end{array}$ & $\begin{array}{l}\text { Dinamikus } \\
\text { medián }\end{array}$ & $-0,02$ & $-1,32$ & $\begin{array}{l}\text { Dinamikus } \\
\text { átlag }\end{array}$ & $\begin{array}{l}\text { Dinamikus } \\
\text { medián }\end{array}$ \\
\hline $\begin{array}{l}\text { Felüljegyzés } \\
\text { (1 bank) }\end{array}$ & $-9,97$ & $-10,27$ & $\begin{array}{c}\text { Dinamikus } \\
\text { medián }\end{array}$ & $\begin{array}{l}\text { Dinamikus } \\
\text { átlag }\end{array}$ & $-0,01$ & $-0,56$ & $\begin{array}{c}\text { Dinamikus } \\
\text { átlag }\end{array}$ & $\begin{array}{l}\text { Dinamikus } \\
\text { medián }\end{array}$ \\
\hline $\begin{array}{l}\text { Aluljegyzés } \\
\text { (1 bank) }\end{array}$ & 10,09 & 10,26 & $\begin{array}{c}\text { Dinamikus } \\
\text { átlag }\end{array}$ & $\begin{array}{l}\text { Dinamikus } \\
\text { medián }\end{array}$ & 0,01 & 0,59 & $\begin{array}{c}\text { Dinamikus } \\
\text { átlag }\end{array}$ & $\begin{array}{l}\text { Dinamikus } \\
\text { medián }\end{array}$ \\
\hline $\begin{array}{l}\text { Aluljegyzés } \\
\text { ( } 2 \text { bank) }\end{array}$ & 17,63 & 21,72 & $\begin{array}{c}\text { Dinamikus } \\
\text { átlag }\end{array}$ & $\begin{array}{l}\text { Dinamikus } \\
\text { medián }\end{array}$ & 0,02 & 1,73 & $\begin{array}{c}\text { Dinamikus } \\
\text { átlag }\end{array}$ & $\begin{array}{l}\text { Dinamikus } \\
\text { medián }\end{array}$ \\
\hline $\begin{array}{l}\text { Aluljegyzés } \\
\text { (3 bank) }\end{array}$ & 22,69 & 28,47 & $\begin{array}{l}\text { Dinamikus } \\
\text { átlag }\end{array}$ & $\begin{array}{l}\text { Dinamikus } \\
\text { medián }\end{array}$ & 0,02 & 3,19 & $\begin{array}{l}\text { Dinamikus } \\
\text { átlag }\end{array}$ & $\begin{array}{l}\text { Dinamikus } \\
\text { medián }\end{array}$ \\
\hline
\end{tabular}

A 2. táblázat a dinamikus szélsőérték-elemzés alapján képzett O/N BUBOR-értékek manipulációs potenciálját tartalmazza. Ezek alapján a dinamikus szélsőérték elemzés is nagyobb manipulációs potenciált hordoz magában olyankor, amikor a jegyzések szórása magas. Ugyanakkor meg kell említeni, hogy a dinamikus átlag alkalmazása alacsonyabb manipulációs potenciált hordoz, mint a jelenleg is alkalmazott trimmelt átlag, amikor a jegyzések szórása alacsony.

\subsection{Korreláló termék árazásának elemzése}

Horváth és Makay (2015) szerint a BUBOR az alapkamathoz képest nem jelenít meg érdemi többletinformációt. Továbbá Csizmadia (2014) következtetéséhez hasonlóan Horváth és Makay (2015) is arra a következtetésre jut, hogy minden alternatív benchmarknak (amellyel a BUBOR korrelálni tudna) van valamely módszertani hiányossága (pl.: FRA-hozamok ${ }^{9}$ ), vagy nincs aktív piaca (pl.: CD-k). Ebből eredően a BUBOR manipulációs gyanújának feltárásához ezt a módszert jelenleg csak erős megkötések mellett lehetne alkalmazni. Emellett minden esetben vizsgálni kellene az egyedi piaci jelenségek, valamint a monetáris politikai eszközök hatásait is, ami meghaladja jelen tanulmány kereteit, illetve célját.

\footnotetext{
${ }^{9}$ Megjelenítik a piaci kamatvárakozásokat, ugyanakkor a hitelkockázat nem jelenik meg benne.
} 


\subsection{Kiugróérték-elemzés}

A kiugróérték-elemzés során a jegyzésben részt vevő intézmények tárgynapi és bázisnapi jegyzésének különbözete került összehasonlításra az elmúlt 250 jegyzési nap saját jegyzéseinek szórásával, illetve annak kétszeres értékével, valamint a BUBOR értékének hasonló módon számított szórásával, illetve annak kétszeres értékével (250 napos visszatekintő szórás). Amennyiben a tárgynapi és bázisnapi különbözet meghaladja a szórást vagy annak kétszeres értékét (választás kérdése, melyiket alkalmazzuk), fennáll a jegyzés manipulációjának gyanúja, így érdemes az aznapi jegyzési folyamatot intézményi szinten kivizsgálni. A kiugróérték-elemzés eredményeit a 3. és 4. táblázat tartalmazza.

\section{3. táblázat}

Kiugróérték-elemzés alapján az intézményi szinten kivizsgálandó esetek számának alakulása 2015 és 2018 között

(1 szórás)

\begin{tabular}{|c|c|c|c|c|c|c|c|c|}
\hline \multirow{2}{*}{$\begin{array}{l}1 \text { szórásnál } \\
\text { nagyobb } \\
\text { változás }\end{array}$} & \multicolumn{4}{|c|}{$\begin{array}{c}\text { Saját jegyzések szórásánál nagyobb } \\
\text { változás }\end{array}$} & \multicolumn{4}{|c|}{ BUBOR szórásánál nagyobb változás } \\
\hline & 2018 & 2017 & 2016 & 2015 & 2018 & 2017 & 2016 & 2015 \\
\hline Bank 12 & 1 & 0 & 11 & 43 & 8 & 0 & 11 & 42 \\
\hline Bank 14 & 5 & 4 & 12 & 43 & 6 & 4 & 12 & 41 \\
\hline Bank 6 & 7 & 3 & 16 & 36 & 22 & 4 & 16 & 39 \\
\hline Bank 1 & 5 & 2 & 0 & 0 & 15 & 6 & 0 & 0 \\
\hline Bank 3 & 3 & 0 & 11 & 34 & 3 & 0 & 10 & 37 \\
\hline Bank 13 & 12 & 3 & 0 & 0 & 18 & 7 & 0 & 0 \\
\hline Bank 7 & 2 & 3 & 8 & 31 & 2 & 4 & 8 & 31 \\
\hline Bank 10 & 6 & 4 & 16 & 37 & 5 & 7 & 17 & 39 \\
\hline Bank 5 & 0 & 0 & 12 & 41 & 0 & 0 & 12 & 41 \\
\hline Bank 11 & 4 & 3 & 11 & 43 & 10 & 4 & 11 & 43 \\
\hline Bank 4 & 0 & 0 & 0 & 0 & 0 & 0 & 0 & 0 \\
\hline Bank 15 & 0 & 0 & 0 & 0 & 0 & 0 & 0 & 0 \\
\hline Bank 8 & 0 & 0 & 0 & 0 & 0 & 0 & 0 & 0 \\
\hline Bank 16 & 0 & 0 & 0 & 0 & 0 & 0 & 0 & 0 \\
\hline Bank 9 & 0 & 0 & 0 & 0 & 0 & 0 & 0 & 0 \\
\hline Bank 2 & 7 & 2 & 15 & 27 & 8 & 3 & 15 & 33 \\
\hline Összesen: & 52 & 24 & 112 & 335 & 97 & 39 & 112 & 346 \\
\hline
\end{tabular}

Megjegyzés: A sötétszürke háttérrel jelölt BUBOR jegyző intézményeknél állt csak rendelkezésre a teljes időszakra vonatkozóan idősor. 


\begin{tabular}{|c|c|c|c|c|c|c|c|c|}
\hline \multicolumn{9}{|l|}{$\begin{array}{l}\text { 4. táblázat } \\
\text { Kiugróérté } \\
\text { alakulása } 2 \\
\text { (2 szórás) }\end{array}$} \\
\hline \multirow{2}{*}{$\begin{array}{l}2 \text { szórásnál } \\
\text { nagyobb } \\
\text { változás }\end{array}$} & \multicolumn{4}{|c|}{$\begin{array}{c}\text { Saját jegyzések szórásánál nagyobb } \\
\text { változás }\end{array}$} & \multicolumn{4}{|c|}{ BUBOR szórásánál nagyobb változás } \\
\hline & 2018 & 2017 & 2016 & 2015 & 2018 & 2017 & 2016 & 2015 \\
\hline Bank 12 & 0 & 0 & 1 & 14 & 0 & 0 & 1 & 13 \\
\hline Bank 14 & 2 & 0 & 1 & 7 & 2 & 0 & 1 & 7 \\
\hline Bank 6 & 1 & 0 & 2 & 8 & 5 & 1 & 2 & 14 \\
\hline Bank 1 & 1 & 0 & 0 & 0 & 2 & 2 & 0 & 0 \\
\hline Bank 3 & 0 & 0 & 0 & 9 & 0 & 0 & 0 & 11 \\
\hline Bank 13 & 1 & 0 & 0 & 0 & 4 & 0 & 0 & 0 \\
\hline Bank 7 & 0 & 2 & 2 & 10 & 0 & 2 & 2 & 9 \\
\hline Bank 10 & 0 & 2 & 3 & 10 & 0 & 4 & 3 & 11 \\
\hline Bank 5 & 0 & 0 & 1 & 10 & 0 & 0 & 1 & 9 \\
\hline Bank 11 & 0 & 0 & 1 & 8 & 2 & 0 & 1 & 8 \\
\hline Bank 4 & 0 & 0 & 0 & 0 & 0 & 0 & 0 & 0 \\
\hline Bank 15 & 0 & 0 & 0 & 0 & 0 & 0 & 0 & 0 \\
\hline Bank 8 & 0 & 0 & 0 & 0 & 0 & 0 & 0 & 0 \\
\hline Bank 16 & 0 & 0 & 0 & 0 & 0 & 0 & 0 & 0 \\
\hline Bank 9 & 0 & 0 & 0 & 0 & 0 & 0 & 0 & 0 \\
\hline Bank 2 & 4 & 0 & 1 & 8 & 4 & 0 & 1 & 11 \\
\hline Összesen: & 9 & 4 & 12 & 84 & 19 & 9 & 12 & 93 \\
\hline
\end{tabular}

Megjegyzés: A sötétszürke háttérrel jelölt BUBOR-jegyző intézményeknél állt csak rendelkezésre a teljes időszakra vonatkozóan idősor.

A 3. és 4. táblázatban összefoglalva, évek szerinti bontásban láthatjuk, hogy a különböző módszerek választása esetén hány alkalommal kellett volna az egyes jegyzésben részt vevő intézményeknek kivizsgálniuk az adott napi jegyzési folyamatot, vagyis hányszor merülhetett fel a módszertan alapján a manipuláció gyanúja.

Fontos ennél a módszernél kihangsúlyozni, hogy az alkalmazott visszatekintési periódus alapvetően befolyásolja a manipulációgyanús esetek számát, így az eredményeket annak tükrében kell mindig értékelni - a jelen cikkben választott 250 napos visszatekintési periódus a kockázatkezelésben elfogadott időtávnak tekinthető. Továbbá, hasonlóan a többi módszerhez, ez a módszer is csak a manipuláció gyanúját veti fel, önmagában nem alkalmas bizonyítani azt. 


\subsection{Alul- és felüljegyzések dinamikájának vizsgálata}

A jegyzések dinamikájának elemzése az előzőekben bemutatott módszerekhez képest kevésbé objektív, mert a BUBOR esetében elsődlegesen nem a jegyzés folyamatában lévő anomáliára, hanem a jegyző intézmény likviditási helyzetére, illetve kockázatkezelési gyakorlatára utal. Minél hosszabb időtávot nézünk, annál stabilabb képet kapunk az egyes jegyző intézményekről. A 3. ábra jól mutatja, hogy melyek azok az intézmények, amelyek inkább felüljegyzőnek, és melyek azok, amelyek inkább aluljegyző intézménynek tekinthetők a 2014 és 2018 augusztusa közötti időszakot vizsgálva.

\section{3. ábra \\ Az O/N BUBOR-jegyzésben részt vevő intézmények jegyzési dinamikája 2014 és 2018 között}

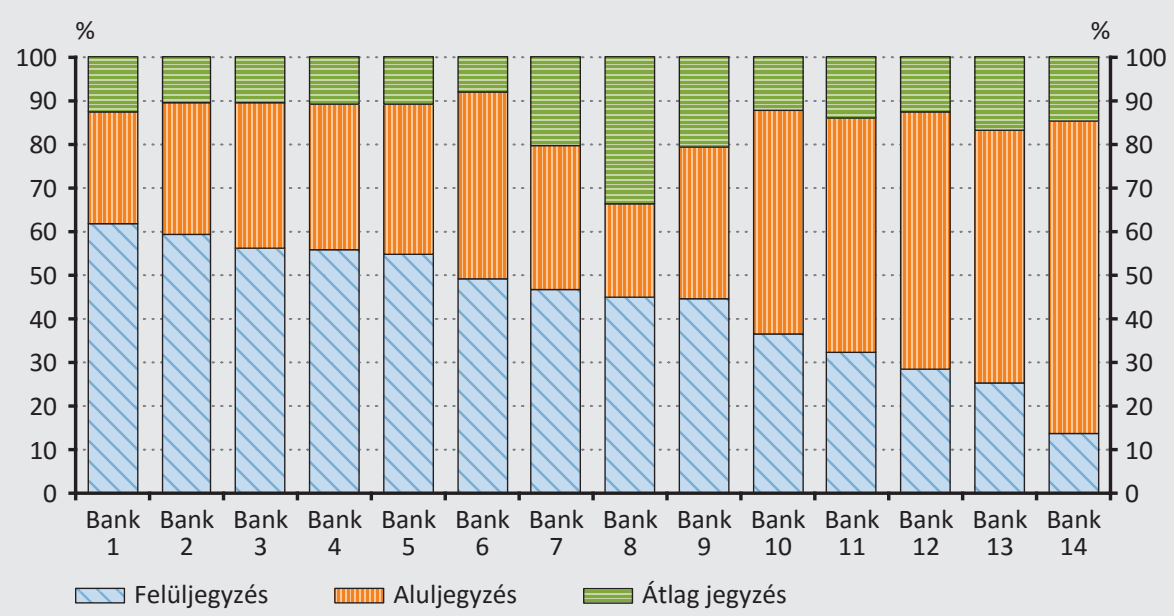

Megjegyzés: Az ábra az átlag körüli tolerancia-sáv nélkül mutatja a jegyzések alakulását.

Az alul- és felüljegyzések dinamikájának elemzése úgy tudja segíteni a manipuláció-gyanú feltárását, hogy a hosszú távon érvényesülő trendet összevetjük egy kiválasztott időszakban megfigyelt intézményi viselkedéssel - ha jelentős az eltérés a rövid távú viselkedés és a hosszú távú trend között, úgy érdemes az időszakot manipuláció szempontjából megvizsgálni. Fontos, hogy a rövidebb időszak legalább egy havi, de inkább negyedéves jegyzési gyakorlatot tükrözzön, mivel ennél rövidebb időszakot nézve nagy valószínűséggel kapunk jelentős eltérést. A módszer önmagában - a többi módszerhez hasonlóan - a manipuláció gyanúját csak jelezni tudja. Figyelembe véve ugyanakkor, hogy a módszer eredményét számos más tényező is befolyásolja (pl.: likviditási helyzet tartós változása), így leginkább ellenőrző módszerként érdemes alkalmazni (amikor valamely más módszer szerint fennáll a manipuláció gyanúja). 


\subsection{Az együttjegyzések elemzése}

Az együttjegyzések klaszterelemzés segítségével kerültek megvizsgálásra, kétfajta módszerrel (legközelebbi szomszéd ${ }^{10}$ és Ward-eljárásokkal). Az együttjegyzések vizsgálatakor is fontos, hogy megfelelő módon válasszuk ki a vizsgált időszakot. Ha túl hosszú időszakot vizsgálunk, akkor az eredményben az együttjegyzések manipulációjának gyanúja egyre kevésbé érhető tetten, mivel a jegyző intézmény egyéb karakterisztikái is megjelennek közvetetten (pl.: lakossági/vállalati profil). Vagyis klaszterelemzéssel a rövidebb távú (1 évnél rövidebb, de negyedévnél nem rövideb $^{11}$ ) viselkedést érdemes vizsgálni.

Jelen tanulmányban a 2018-as ${ }^{12}$ O/N BUBOR-jegyzések kerültek összevetésre azoknál a jegyző intézményeknél, ahol az idősor teljes, 2018 januárjától 2018 augusztusáig tartó időszakra rendelkezésre állt.

Együttjegyzéses manipuláció gyanúja akkor merül fel, ha két vagy több jegyzésben részt vevő intézmény a különböző távolságmérési és hasonlóságmértéken alapuló módszer alkalmazása mellett stabilan együtt jegyez. Egyszerübben megfogalmazva, az alkalmazott módszertől függetlenül azonos csoportba sorolja őket a módszer. A 4. és 5. ábra mutatja az elkészült dendrogramokat.

\section{4. ábra \\ Együttjegyzések vizsgálata \\ (2018 jan-aug)}

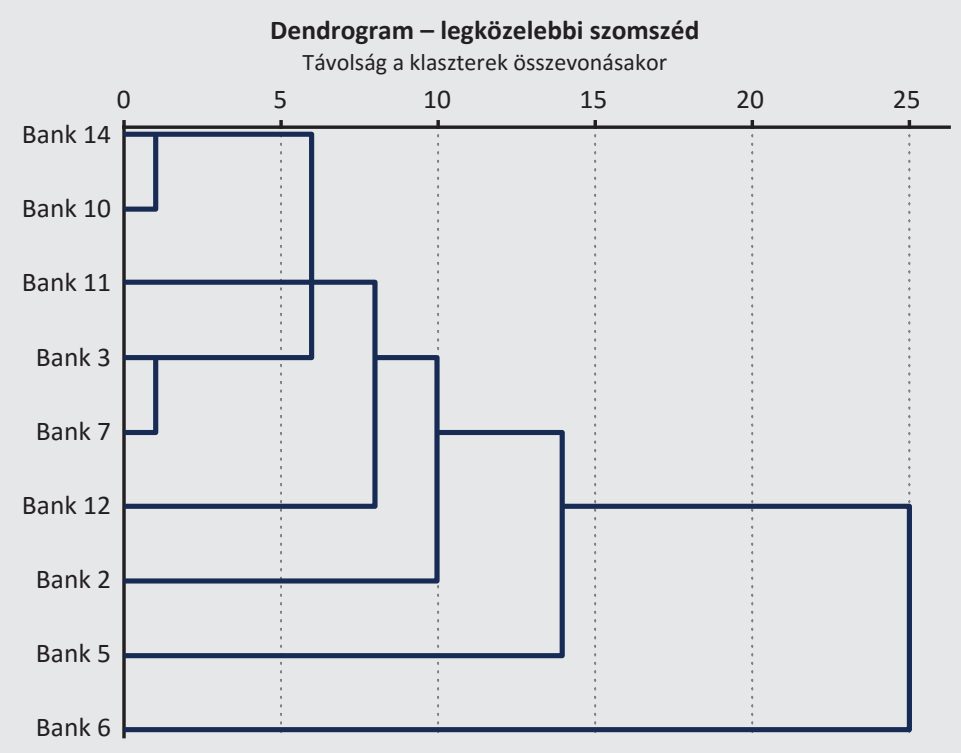

10 nearest neighbour

11 Klaszterelemzést csak megfelelő számú jegyzés esetében lehet végezni.

12 2018. január 1-től 2018. augusztus 15-ig 


\section{5. ábra \\ Együttjegyzések vizsgálata (Ward) \\ (2018 jan-aug)}

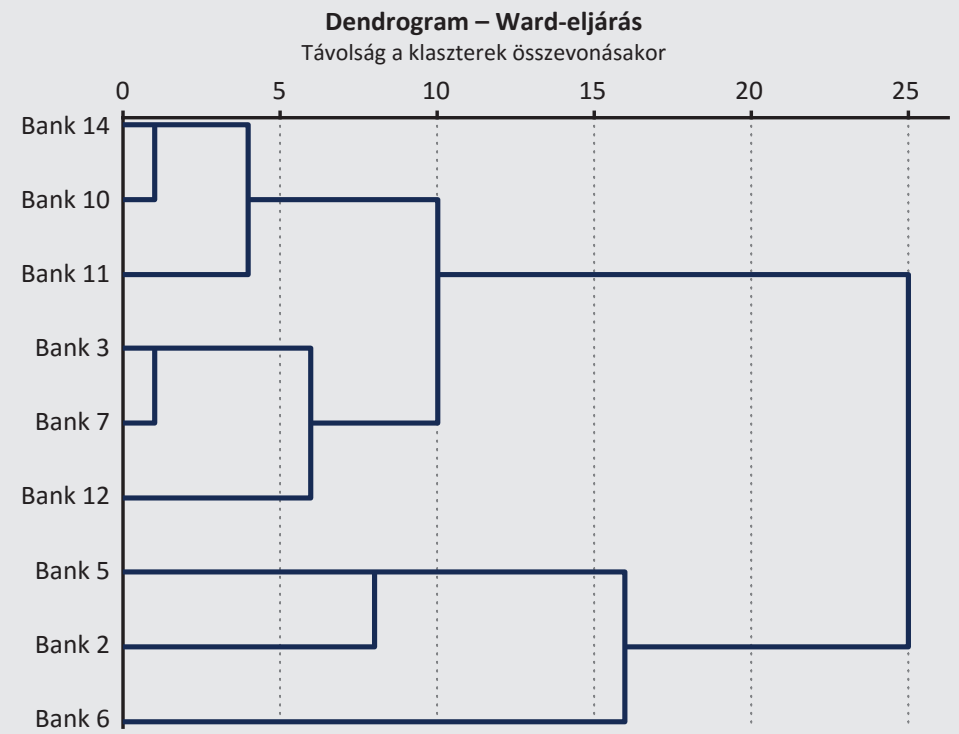

A dendrogramokon jól látható, hogy vannak olyan intézmények, amelyek mindkét módszer szerint együtt jegyeznek (Bank 10 és Bank 14, illetve Bank 3 és Bank 7), a manipuláció gyanúja tehát felmerül. Ugyanerre az időszakra vonatkozóan az alul és felüljegyzések dinamikáját vizsgálva - mint ellenőrző módszer - részben alátámasztható a klaszterelemzés eredménye, mivel a Bank 10 és Bank 14 közel azonos arányban jegyez felül (lásd 6. ábra). A Bank 7 és Bank 3 viszonylatában már nem ennyire egyértelmű az összefüggés, tekintve, hogy a Bank 7 lényegesen magasabb arányban jegyzett az átlag szerint, mint a Bank 3. 


\section{6. ábra}

Az O/N BUBOR-jegyzésben részt vevő intézmények jegyzési dinamikája 2018-ban

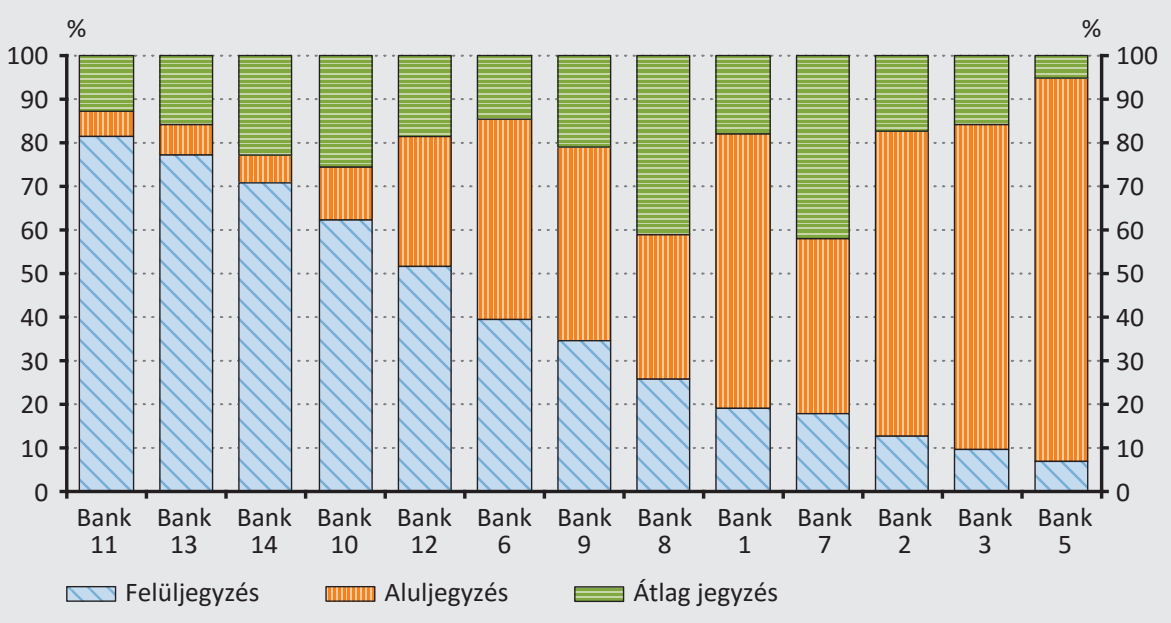

Ha figyelembe vesszük a vizsgált időszakban a piacot jellemző alacsony kamatkörnyezetet, likviditástöbbletet, valamint részben az előző tényezők következményeként a jegyzések alacsony szórását is, akkor a manipulációs gyanú nem tekinthető alátámasztottnak a Bank 10 és Bank 14 esetében sem. Számszerúen, a jegybank által alkalmazott módszertan alapján a referenciamutató manipulációs potenciálja két bank összejátszása esetén sem lenne jelentős (5. táblázat).

\begin{tabular}{|c|c|}
\hline $\begin{array}{l}\text { 5. táblázat } \\
\text { Manipulációs potenciál trimmelt át }\end{array}$ & latilitás mellett \\
\hline Trimmelt átlag & $\begin{array}{l}\text { Manipulációs potenciál } \\
\text { (bázispont) }\end{array}$ \\
\hline Aluljegyzés manipuláció (3 bank) & 2,02 \\
\hline Aluljegyzés manipuláció ( 2 bank) & 0,94 \\
\hline Aluljegyzés manipuláció (1 bank) & 0,38 \\
\hline Felüljegyzés manipuláció (1 bank) & $-0,63$ \\
\hline Felüljegyzés manipuláció (2 bank) & $-1,21$ \\
\hline Felüljegyzés manipuláció (3 bank) & $-2,06$ \\
\hline
\end{tabular}

A fentiek alapján levonhatjuk a következtetést, hogy az együttjegyzések klaszterelemzéssel történő elemzése a referenciamutató alapjául szolgáló jegyzések nagyobb szórása esetén hatékonyabb eszköz lehet, mint a jegyzések alacsony szórása mellett. Mindenesetre, a vizsgált időszakra vonatkozó manipulációs potenciált is figyelembe 
véve bebizonyosodott - ahogy arról már korábban volt szó -, hogy önmagában ez a módszer sem alkalmas arra, hogy a manipulációs gyanút igazolja.

\section{Következtetések}

A referenciamutatóként használt bankközi kamatlábak manipulációs kockázatának minimális szintre történő csökkentéséhez elengedhetetlen megérteni azokat a múltbeli folyamatokat, amelyek formálták a referenciamutatók kialakulását, illetve fejlődését. Ebben a tekintetben Fliszár (2016) fogalmazza meg az alapvető különbséget a manipulációba keveredett LIBOR számítása és a BUBOR számítása között. Eszerint a LIBOR esetében a számítás alapjául szolgáló adatok a jegyző intézmények önbevallásán alapultak a LIBOR-botrány kitörése előtt, és elviekben azt tükrözték, hogy adott intézmények milyen költség mellett jutnak forráshoz. A BUBOR esetében viszont azt tükrözte, hogy milyen forrásköltség mellett nyújtanának a bankok egymásnak fedezetlen hitelt. Vagyis az egyik önminősítés alapú volt, míg a másik a piacot minősítette. Ebben a tekintetben az önminősítés esetében jelentősen nagyobb az ösztönzés a manipulációra, míg a másik esetben a partnerintézmények kockázatának minősítése jelentős manipuláció-ellenösztönzőként is megjelent.

Egy referenciamutató tekintetében fontos tisztában lenni azzal is, hogy milyen mértékben van kitéve egy esetleges manipulációnak. A BUBOR esetében két eltérő időszak 6-6 szcenárió mentén került megvizsgálásra. Ezek alapján alacsony jegyzési volatilitás mellett a legrosszabb módszer (dinamikus átlag) alkalmazásával a manipulációs potenciál 3 intézmény együttjegyzése mellett sem közelítette meg a 4 bázispontot. A legjobb módszerrel (számtani átlag) ez az érték 0,01 bázispont volt. Magas jegyzési volatilitás mellett a legrosszabb módszer (dinamikus medián) alkalmazása mellett, 3 együttjegyző bankot feltételezve 28,47 bázispontos manipulációs potenciált lehetett elérni, míg a legjobb módszerrel (trimmelt medián) ez az érték csupán 9,64 bázispontos volt. Fontos még kiemelni, hogy a BUBOR aluljegyzési manipulációs potenciálja lényegesen magasabb, mint a felüljegyzési. Az alkalmazott módszerek tekintetében az alacsony jegyzési volatilitás mellett az egyszerű számtani átlag, míg a jegyzések magas volatilitása esetén a trimmelt medián és a trimmelt átlag teljesített a legjobban.

Figyelembe véve, hogy a bankközi kamatláb manipulációja azonnal (a felmerülés pillanatában) nem detektálható ésszerű ellenőrzési költségek mellett, érdemes azokra a módszerekre helyezni a hangsúlyt, amelyek egyfelől csökkentik a manipuláció lehetőségét, másfelől pedig növelik a manipuláció feltárásának lehetőségét. A 6 . táblázat a jelen cikkben bemutatott módszereket tartalmazza, aszerint, hogy a rendelkezésre álló adatok tekintetében hol lehetséges implementálni. 


\section{6. táblázat}

A jegyzési manipuláció megelőzésére, illetve feltárására használható módszerek intézményi implementálhatóság szerint

\begin{tabular}{l|c|c|c}
\multicolumn{1}{c|}{ Módszer megnevezése } & $\begin{array}{c}\text { Referenciakamat- } \\
\text { előállító }\end{array}$ & $\begin{array}{c}\text { Adatszolgáltató } \\
\text { (jegyzö) }\end{array}$ & Felügyelet \\
\hline $\begin{array}{l}\text { Átlag-, medián-, trimmelt átlag- és } \\
\text { trimmelt medián-jegyzések }\end{array}$ & $\mathrm{X}$ & $\mathrm{X}$ \\
\hline Dinamikus szélsőérték-elemzés & $\mathrm{X}$ & $\mathrm{X}$ & $\mathrm{X}$ \\
\hline Korreláló termék árazásának elemzése & $\mathrm{X}$ & $\mathrm{X}$ & $\mathrm{X}$ \\
\hline Kiugróérték-elemzés & $\mathrm{X}$ & $\mathrm{X}$ \\
\hline $\begin{array}{l}\text { Alul- és felüljegyzések dinamikájának } \\
\text { vizsgálata }\end{array}$ & $\mathrm{X}$ & $\mathrm{X}$ & $\mathrm{X}$ \\
\hline Kitüntetett napok vizsgálata & & $\mathrm{X}$ \\
\hline Együttjegyzések elemzése & & & \\
\hline
\end{tabular}

A táblázatban nem szerepel a fizetési rendszer adatain alapuló referenciakamat-előállítás. Ennek oka, hogy a nagy értékű azonnali fizetési rendszerek rendszerüzemeltetője több szerepkörben is megjelenhet (pl.: referenciakamat-előállító intézmény, jegybank, felügyelet stb.).

A referenciakamat előállítására használt módszerek a manipulációs potenciált csökkentik, míg az intézményi és felügyeleti szinten implementálható módszerek a manipuláció feltárásának valószínűségét növelik.

Összességében elmondhatjuk, hogy az alacsony kamatkörnyezet és a jegyzések alacsony szórása az alkalmazott módszertannal együtt gyakorlatilag a nulla közeli szintre csökkentette a manipulációs potenciált. Ez egyben azt is jelenti, hogy azokban az időszakokban, amikor a jegyzések volatilitása alacsony, a referenciamutató képzésének ellenőrzésére fordított erőforrások mennyiségének a csökkentése indokolt és alátámasztott.

Végül, de nem utolsó sorban meg kell jegyezni azt is, hogy egyes módszerek bevezetése a jegyzésben részt vevő intézmények alkalmazkodását válthatja ki, ami gyengítheti, illetve erősítheti is egy-egy módszer hatékonyságát. 


\section{Felhasznált irodalom}

Altunbas, Y. - Gadanecz, B. - Kara, A. (2006): The evolution of syndicated loan markets. The Service Industries Journal. 26(6): 689-707. https://doi.org/10.1080/02642060600851129

Borszéki Éva (2009): Bevezetés a nemzetközi pénzügyekbe. Szent István Egyetem, Gödöllő.

Brousseau, V. - Chailloux, A. - Durré, A. (2009): Interbank Offered Rate: Effects of the Financial Crisis on the Information Content of the Fixing. IÉSEG School of Management Working Paper No. 2009-ECO-10. http://dx.doi.org/10.2139/ssrn.1635890

Choy, M. - Shung, K. P. - Chng, E. (2012): Interest Rate Manipulation Detection using Time Series Clustering Approach. https://arxiv.org/ftp/arxiv/papers/1208/1208.2878.pdf. Letöltés ideje: 2018. augusztus 15.

Csizmadia Péter (2014): A globális válság hatásának vizsgálata a magyar kamattermékek piacára. PhD-értekezés, Nyugat-Magyarországi Egyetem. http://dx.doi.org/10.13147/ NYME.2014.026

Cutler, D. - Ridley, K. (2013): Timeline: How the LIBOR Scandal Unfolded. REUTERS. https:// www.reuters.com/article/us-libor-rbs-scandal/timeline-how-the-libor-scandal-unfoldedidUSBRE9150TB20130206. Letöltés ideje: 2018. augusztus 2.

ECB (2018): ESTER Methodology and policies. European Central Bank, Frankfurt. https:// www.ecb.europa.eu/paym/initiatives/interest_rate_benchmarks/shared/pdf/ecb.ESTER_ methodology_and_policies.en.pdf. Letöltés ideje: 2019. február 2.

Eisl, A. - Jankowitsch, R. - Subrahmanyam, M. G. (2017): The Manipulation Potential of LIBOR and EURIBOR. European Financial Management, 23(4): 604-647. https://doi.org/10.1111/ eufm.12126

Erhart Szilárd - Mátrai Róbert (2015): A jegybank által vezérelt BUBOR-reformok legfontosabb lépései nemzetközi összehasonlításban. Hitelintézeti Szemle, 14(1): 139-165. http://www. hitelintezetiszemle.hu/letoltes/6-erhart-matrai-2.pdf

Farkas Richárd - Mosolygó Zsuzsa - Páles Judit (2004): A kamatswappiac hazai perspektivái adósságkezelési megközelítésből. Hitelintézeti Szemle, 3(6): 1-24. http://www. bankszovetseg.hu/Content/Hitelintezeti/46Farkas.pdf

Fliszár Vilmos (2016): Budapesti bankközi hitelkamatláb a londoni bankközi referenciakamatláb árnyékában. PhD-értekezés, Budapesti Corvinus Egyetem. http://dx.doi. org/10.14267/phd.2016014 
Frost, J. (2017): Introducing the Secured Overnight Financing Rate (SOFR). Federal Reserve Bank of New York, ARRC Roundtable, New York. https://www.newyorkfed.org/medialibrary/ media/newsevents/speeches/2017/Frostpresentation.pdf. Letöltés ideje: 2019. február 2.

Gadanecz, B. (2004): The syndicated loan market: structure, development and implications. BIS Quarterly Review, 2004(December): 75-89.

Gereben Áron (2000): The Interbank Money Market in Hungary (Lessons from the Period between September 1998 and March 1999). MNB Occasional Papers No. 7. https://www. mnb.hu/letoltes/op-7.pdf. Letöltés ideje: 2018. augusztus 22.

Gyntelberg, J. - Wooldridge, P. (2008): Interbank rate fixings during the recent turmoil. BIS Quarterly Review, 2008(March): 59-72.

Hardin, G. (1968): The Tragedy of the Commons. Science, 162(3859): 1243-1248. http:// dx.doi.org/10.1126/science.162.3859.1243

Horváth Dániel - Makay Eszter (2015): A bankközi referenciakamatok meghatározásának elemzési módszertana - Nemzetközi trendek és a 2014-re vonatkozó, első hazai éves statisztikai vizsgálat eredményei. Hitelintézeti Szemle, 14(2): 62-87. http://www. hitelintezetiszemle.hu/letoltes/3-horvath-makay.pdf

Horváth Dániel - Kálmán Péter - Kolozsi Pál Péter (2017): A BUBOR és a hazai bankközi piac fejlesztése. In: Magyar Nemzeti Bank: A magyar út - célzott jegybanki politika, pp. 497-526.

IOSCO (2013): Principles for Financial Benchmarks. https://www.iosco.org/library/pubdocs/ pdf/IOSCOPD415.pdf. Letöltés ideje: 2018. július 10.

Kocsis Zalán - Csávás Csaba - Mák István - Pulai Gyula (2013): Kamatderivatíva-piacok Magyarországon 2009 és 2012 között a K14-es adatszolgáltatás tükrében. MNB tanulmányok 107. https://www.mnb.hu/letoltes/mt107.pdf. Letöltés ideje: 2019. február 1.

Kuprianov, A. (1993): Over-the-Counter Interest Rate Derivatives. Federal Reserve Bank of Richmond Economic Quarterly, 79(3): 65-94.

MNB (2000): A BUBOR szerepe a monetáris politika múködtetésében és a kamattranszmiszszióban - Feljegyzés a Pénzpiaci Konzultativ Fórum részére. https://www.mnb.hu/letoltes/ forum-2000062002.pdf. Letöltés ideje: 2018. augusztus 11.

MNB (2018): Szabályzat a Budapesti Bankközi Forint Hitelkamatláb jegyzési eljárásáról, a jegyzési követelményeiröl, valamint a kamatjegyző bankok által követett magatartási szabályzatoktól. https://www.mnb.hu/letoltes/bubor-szabalyzat.pdf. Letöltés ideje: 2018. augusztus 15.

Mollencamp, C. (2008): Bankers Cast Doubt On Key Rate Amid Crisis. The Wall Street Journal. 
Monticini, A. - Thornton D. L. (2013): The Effect of Underreporting on LIBOR rates. FED. http:// www.monticini.eu/pub/libscandal.pdf. Letöltés ideje: 2018. szeptember 3.

Ridley, K. - Jones, H. (2012): A Greek Banker Spills On The Early Days Of The Libor And His First Deal With The Shah Of Iran. Reuters. https://www.businessinsider.com.au/historyof-the-libor-rate-2012-8. Letöltés ideje: 2018. augusztus 15.

Sajtos László - Mitev Ariel (2007): SPSS kutatási és adatelemzési kézikönyv. Alinea Kiadó, Budapest.

Tarján M. Tamás (2018): 1947. június 5. A Marshall-terv meghirdetése. Rubicon. http://www. rubicon.hu/magyar/oldalak/1947_junius_5_a_marshall_terv_meghirdetese/. Letöltés ideje: 2018. augusztus 18. 